\title{
Immune System Response to Aerobic Exercise Training in Obese Females
}

\author{
Azza Fekri Ismail*, Shehab M A. Kader*, Soheir Abo EL Fadl**, \\ Nashwa El Tablawy*** \\ * Department of Physical Therapy for Cardiopulmonary Disorders and \\ Geriatrics, Faculty of Physical Therapy, Cairo University \\ ** Internal Medicine and *** Physiology Departments \\ Faculty of Medicine, Cairo University
}

\begin{abstract}
Background: Obesity has a bad impact on immune system; on the other hand moderate exercise increases the resistance to infection. The aim of this study was to determine the response of complement system to aerobic exercise training in obese females. Subjects and methods: Thirty obese females participated in this study and they were divided randomly into two equal groups; the exercise group (group-1) which received aerobic exercise training for 4 months and the non-exercised group (group-2) which maintained their ordinary life style. Thirty age-matched non-obese females were the control group. Measurements of serum complement proteins (C3 and C4) were done at the start and at the end of the study, also the body mass index (BMI) was calculated at the start and at the end of the study. Results: at the start of the study; there was a significantly high levels of C3 \& C4 in obese compared to the control (non-obese) females $(P=0.000)$. At the end of the study; there was a significant decrease in BMI, C3 \& C4 in the exercise group compared to the nonexercised group, also there was a significant differences between the measures at the start and at the end of the study in the exercise group as regards BMI, C3 \& C4. Conclusion: obesity causes changes in the immune system as documented by increase in C3 \& C4 levels. Moderate aerobic exercise produced weight reduction and decreased the abnormally elevated complement components (C3 \& C4) in obese females; so improving the immune system.
\end{abstract}

Key words: complement system, aerobic exercise, immunity and obesity.

\section{INTRODUCTION}

Obesity has a serious effect on the immune system; fat tissue attracts immune system cells called macrophages that promote inflammation in the body. So if there is any extra fat, the body begins to produce an immune response similar to the reaction against infection or injury ${ }^{1}$. Recent study demonstrates that excessive activation of the classic pathway of complement commonly occurs in obesity, suggesting its possible role in adipose tissue inflammation and insulin resistance ${ }^{2}$.

Complement was discovered many years ago as a heat-labile 
component of normal plasma that augments the opsonization of bacteria by antibodies and allows antibodies to kill some bacteria. Complement proteins are produced constitutively by macrophages and hepatocytes, and are present in the circulation as inactive molecules. Several complement proteins are proenzymes. When activated, they become proteases that cut peptide bonds in other complement proteins to activate them in turn. Since each activated protease can activate many substrate molecules, the initial activation is rapidly amplified to produce millions of effectors molecules (a cascade) to opsonize pathogens and induce a series of inflammatory responses that help to fight infection. Complement C3 and $\mathrm{C} 4$ are the major plasma proteins of the immune system complement pathways. The synthesis of these proteins is increased in response to inflammation and infection ${ }^{3}$.

Previous studies have shown that several aspects of the metabolic syndrome, which in itself is tightly linked to visceral obesity, are associated with chronically elevated serum levels of acute-phase markers ${ }^{4}$. In particular, increased levels of $\mathrm{C}$ reactive protein (CRP) and complement $\mathrm{C} 3$ can predict risk for future cardiovascular events, and both are negatively correlated with insulin sensitivity in obese subjects ${ }^{5-8}$. High C3 levels have been reported in subjects with diabetes and insulin resistance. The metabolic syndrome is associated with chronically elevated levels of several immune markers, some of which may have metabolic effects. The high expression of complement genes in intra-abdominal adipose tissue might suggest that the complement system is involved in the development of visceral adiposity and/or contributes to the metabolic complications associated with increased visceral fat mass 9 .

Regular exercise has a favorable influence over many systems throughout the body and improves one's sense of well-being and general fitness. Much research has been carried out on the effects of exercise on immune and hormonal parameters in healthy individuals ${ }^{10}$. Several studies provide epidemiological evidence that regular exercise increases resistance to infections such as common cold whereas intense training is associated with increased upper respiratory tract infections ${ }^{\mathbf{1 1}}$.

The aim of this study was to determine the response of complement system to aerobic exercise training in obese females.

\section{SUBJECT \& METHODS}

\section{Subjects:}

Thirty obese females (with no other medical problems) were selected from the outpatient clinic of internal medicine in Kasr El-Aini hospital. Their ages ranged from 25-37 years \& their BMI ranged from $30-35 \mathrm{~kg} / \mathrm{m}^{2}$. The patients were randomly allocated (by mean of random numbers) into one of two equal groups; group 1: the exercise group which received aerobic exercise training for 4 months and group 2: the non-exercise group which maintained their ordinary life style. The training exercises were conducted in the out patient clinic of Faculty of Physical Therapy. Thirty 
healthy non-obese females were selected as a control group. Their ages ranged from 26-36 years \& their BMI ranged from $21-24.5 \mathrm{~kg} / \mathrm{m}^{2}$

Equipment and measurements:

1. Commercial kits to measure the serum levels of complement proteins (C3 \& C4)

2. Weight and height scale (Metro type-England) was used to measure the weight and height to calculate the BMI. BMI=weight in $\mathrm{kg} /$ height in $\mathrm{m}^{2}$.

3. Treadmill (Enraf Nonium, Model display panel standard, NR 1475.801, Holland) was used for walking exercises.

Measurement of C3 \& C4 and calculation of BMI were done before starting the study for the obese and non-obese and control subjects and repeated at the end of the study (after four months) for the obese subjects.

Procedure:

Group 1: (15 females) received exercise training on bicycles ergometer; 3 sessions weekly, each session started with 5 minutes of aerobic exercise in the form of stretching exercise and walking in place (warm-up). Then the subject started the bicycle ergometer training for 40 minutes with an intensity of $65 \%$ of maximal heart rate for one month and increased gradually to $85 \%$ of maximal heart rate during the next three months of the program. The workload is gradually reduced over 5 minutes (cool down).

Group 2: (15 females) asked to maintain their ordinary life style.

Statistical analysis:

Data were summarized using the mean $( \pm \mathrm{SD})$. " $t$ " test was used for comparisons between the mean values of C3 \& C4 of the complement system and BMI in obese and control subjects and comparisons between the mean values of $\mathrm{C} 3 \& \mathrm{C} 4$ of the complement system and BMI obtained before and after 4 months in the non-exercised and exercise group. Pearson's correlation test was used for correlation between BMI \& complement "C3". $\mathrm{P}$ value is significant if $<0.05$.

\section{RESULTS}

Table (1) and figure (1) show comparison between non-obese (control) and obese subjects. There was no significant difference as regards the age. There were significant increase in the levels of C3 $\& \mathrm{C} 4$ and $\mathrm{BMI}$ in obese compared to non-obese subjects.

Table (1): Comparison between control \& obese subjects as regards age, BMI, C3 \&C4

\begin{tabular}{|c|c|c|c|}
\hline Variables & $\begin{array}{c}\text { Non-obese (control group) } \\
\mathbf{N}=\mathbf{3 0} \\
\text { Mean }( \pm \text { SD) }\end{array}$ & $\begin{array}{c}\text { Obese subjects } \\
\mathbf{N}=\mathbf{3 0} \\
\text { Mean }( \pm \text { SD) }\end{array}$ & P value \\
\hline Age $(\mathrm{years})$ & $30.4 \pm 3.86$ & $28.9 \pm 5.78$ & 0.24 \\
\hline $\mathrm{BMI}\left(\mathrm{kg} / \mathrm{m}^{2}\right)$ & $22.87 \pm 1.1$ & $33.52 \pm 2.2$ & $0.001^{*}$ \\
\hline $\mathrm{C} 3(\mathrm{mg} / \mathrm{dl})$ & $115.57 \pm 23.3$ & $179.83 \pm 8.69$ & $0.001^{*}$ \\
\hline $\mathrm{C} 4(\mathrm{mg} / \mathrm{dl})$ & $19.67 \pm 6.9$ & $40.03 \pm 1.87$ & $0.001^{*}$ \\
\hline
\end{tabular}




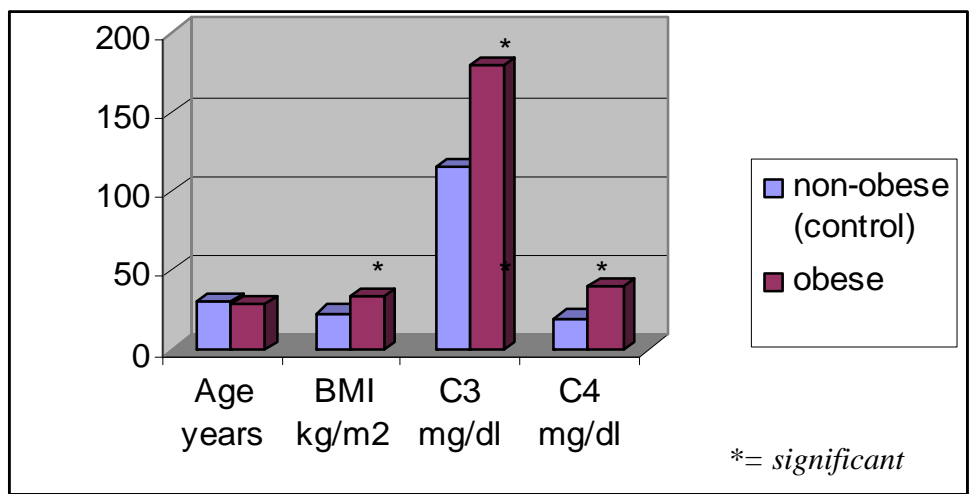

Fig. (1): shows significant differences in BMI, C3 \&C4 between control \& obese subjects

Table (2): Correlation between BMI and both $\mathrm{C} 3$ \& $\mathrm{C} 4$ in obese subjects

\begin{tabular}{|c|c|c|}
\hline Parameter & \multicolumn{2}{|c|}{ BMI } \\
\hline & $\mathrm{r}$ & P value \\
\hline $\mathrm{C} 3(\mathrm{mg} / \mathrm{dl})$ & 0.52 & $0.006^{*}$ \\
\hline $\mathrm{C} 4(\mathrm{mg} / \mathrm{dl})$ & 0.32 & $0.04^{*}$ \\
\hline
\end{tabular}

*=significant

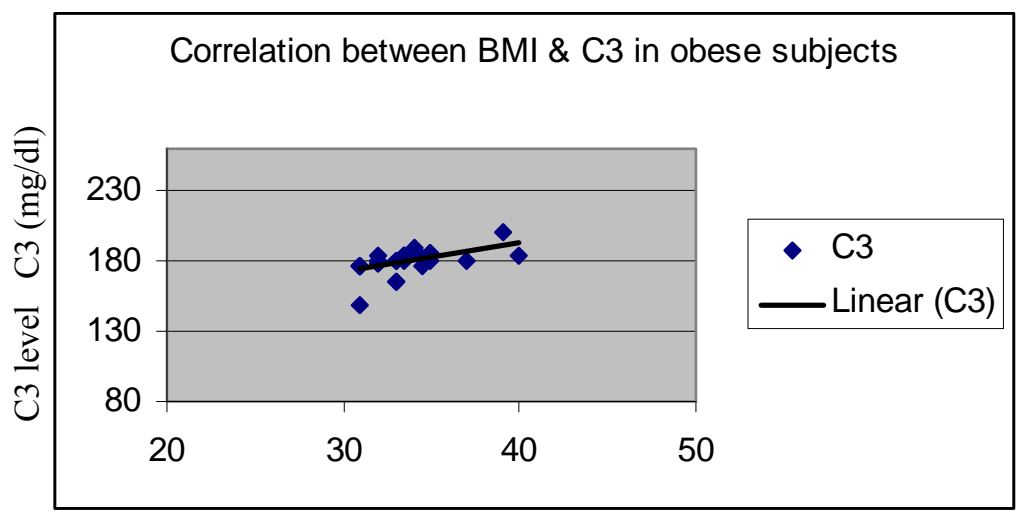

BMI $\left(\mathrm{kg} / \mathrm{m}^{2}\right)$

Figure (2) shows positive correlation between BMI \& C3 in obese subjects

Table (3) and figure (3) show the differences between the $\mathrm{C} 3, \mathrm{C} 4$ levels \& BMI at the start and the end of the study in the exercise group (group 1). There were significant decreases in the mean values of $\mathrm{C} 3$, C4 \& BMI in group (1) after the four months training exercise program. $\mathrm{P}$ value $<0.05$. 
Table (3): comparison between the start \& the end values of $\mathrm{C3}, \mathrm{C} 4 \& \mathrm{BMI}$ in obese exercised group (1)

\begin{tabular}{|l|l|l|l|}
\hline \multirow{2}{*}{\multicolumn{1}{|c|}{ Variables }} & \multicolumn{2}{c|}{ Mean \pm SD } & \multirow{2}{*}{ P value } \\
\cline { 2 - 3 } & \multicolumn{1}{|c|}{ At the start } & \multicolumn{1}{c|}{ At the end } & \\
\hline $\mathrm{C} 3(\mathrm{mg} / \mathrm{dl})$ & $178.3 \pm 9.87$ & $133.4 \pm 14.02$ & $0.000^{*}$ \\
\hline $\mathrm{C} 4(\mathrm{mg} / \mathrm{dl})$ & $39.4 \pm 1.68$ & $31.47 \pm 5.1$ & $0.000^{*}$ \\
\hline $\mathrm{BMI}\left(\mathrm{kg} / \mathrm{m}^{2}\right)$ & $32.96 \pm 1.3$ & $27.33 \pm 1.87$ & $0.000^{*}$ \\
\hline
\end{tabular}

C3= complement 3 C4= complement $4 \quad B M I=$ body mass index $*=$ significant

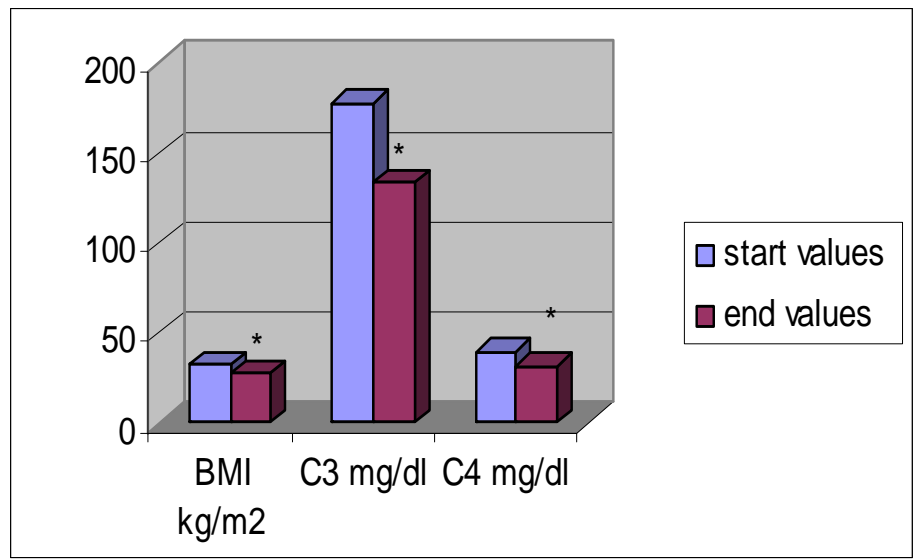

Fig. (3): Comparison between the start \& end values of C3, C4 \& BMI in group (1). The differences between the start and end values of C3, C4 \& BMI in the nonexercise group (group 2) were shown in table (4) and figure (4). There were no significant differences between the pre and post measures. P-value $>0.05$

Table (4): comparison between the start \& the end values of $\mathrm{C3}, \mathrm{C} 4 \& \mathrm{BMI}$ in obese non exercised (group 2)

\begin{tabular}{|l|l|l|l|}
\hline \multirow{2}{*}{\multicolumn{1}{|c|}{ Variables }} & \multicolumn{2}{c|}{ Mean \pm SD } & \multirow{2}{*}{ P value } \\
\cline { 2 - 3 } & \multicolumn{1}{|c|}{ At the start } & \multicolumn{1}{c|}{ At the end } & \\
\hline $\mathrm{C} 3(\mathrm{mg} / \mathrm{dl})$ & $181.4 \pm 7.34$ & $186.8 \pm 13.36$ & $0.25(\mathrm{NS})$ \\
\hline $\mathrm{C} 4(\mathrm{mg} / \mathrm{dl})$ & $40.6 \pm 1.92$ & $38.13 \pm 5.76$ & $0.16(\mathrm{NS})$ \\
\hline $\mathrm{BMI}\left(\mathrm{kg} / \mathrm{m}^{2}\right)$ & $34.08 \pm 2.77$ & $34.25 \pm 4.4$ & $0.89(\mathrm{NS})$ \\
\hline
\end{tabular}

NS= non significant 


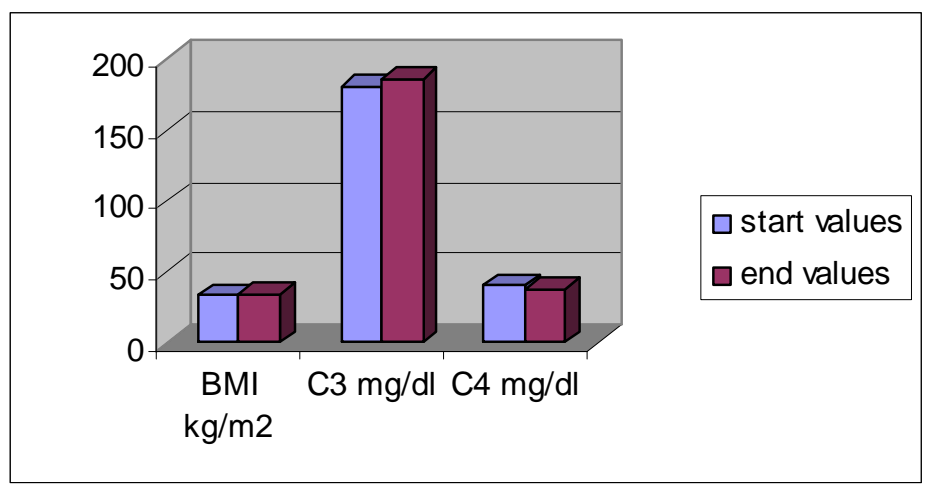

Fig. (4): Shows no significant differences between the start \& the end values of C3, $C 4$ \& BMI in group (2)

Comparison between group (1) \& group (2) at the start of the study reveled no significant differences as regards BMI, C3 \& C4 (table 5) \& (figure 5).

Table (5): Comparison between group (1) \& group (2) as regards C3, C4 \& BMI at the start of the study:

\begin{tabular}{|l|c|c|c|}
\hline \multirow{2}{*}{ Variables } & \multicolumn{2}{|c|}{ Means \pm SD } & \multirow{2}{*}{ P value } \\
\cline { 2 - 3 } & Exercise group(1) & Non-exercise group (2) & \\
\hline $\mathrm{C} 3(\mathrm{mg} / \mathrm{dl})$ & $178.3 \pm 9.87$ & $181.4 \pm 7.34$ & $0.1(\mathrm{NS})$ \\
\hline $\mathrm{C} 4(\mathrm{mg} / \mathrm{dl})$ & $39.4 \pm 1.68$ & $40.6 \pm 1.92$ & $0.28(\mathrm{NS})$ \\
\hline $\mathrm{MBI}\left(\mathrm{kg} / \mathrm{m}^{2}\right)$ & $32.96 \pm 1.3$ & $34.08 \pm 2.77$ & $0.1(\mathrm{NS})$ \\
\hline
\end{tabular}

NS= non significant $\quad C 3=$ complement $3 \quad C 4=$ complement $B M I=$ body mass index

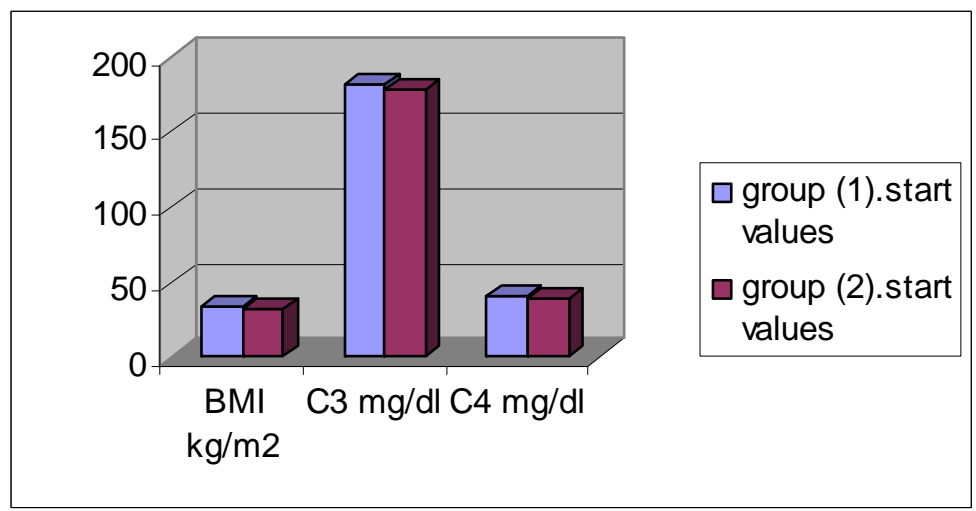

Fig. (5) Shows no significant differences between group 1 \& 2 as regards BMI, C3 \& C4 at the start of study 
Comparison between obese exercised group (1) \& obese nonexercised group (2) at the end of the study reveled significant differences as regards BMI, C3 \& C4 (table 6) \& (figure 6). There were significant decrease in BMI, C3 \& C4 in the exercise group compared to non-exercise group (P-value $<0.05)$.

Table (6): comparison between group (1) \& group (2) as regards $\mathrm{C3}, \mathrm{C} 4 \& \mathrm{BMI}$ at the end of the study:

\begin{tabular}{|l|l|l|l|}
\hline \multirow{2}{*}{ Variables } & \multicolumn{2}{c|}{ Mean SD } & \multirow{2}{*}{ P value } \\
\cline { 2 - 3 } & Exercise group(1) & Control group (2) & \\
\hline $\mathrm{C} 3(\mathrm{mg} / \mathrm{dl})$ & $133.4 \pm 14.02$ & $186.8 \pm 13.36$ & $0.000^{*}$ \\
\hline $\mathrm{C} 4(\mathrm{mg} / \mathrm{dl})$ & $31.47 \pm 5.1$ & $38.13 \pm 5.76$ & $0.000^{*}$ \\
\hline $\mathrm{BMI}\left(\mathrm{kg} / \mathrm{m}^{2}\right)$ & $27.33 \pm 1.87$ & $34.25 \pm 4.4$ & $0.002^{*}$ \\
\hline
\end{tabular}

$*=$ significant

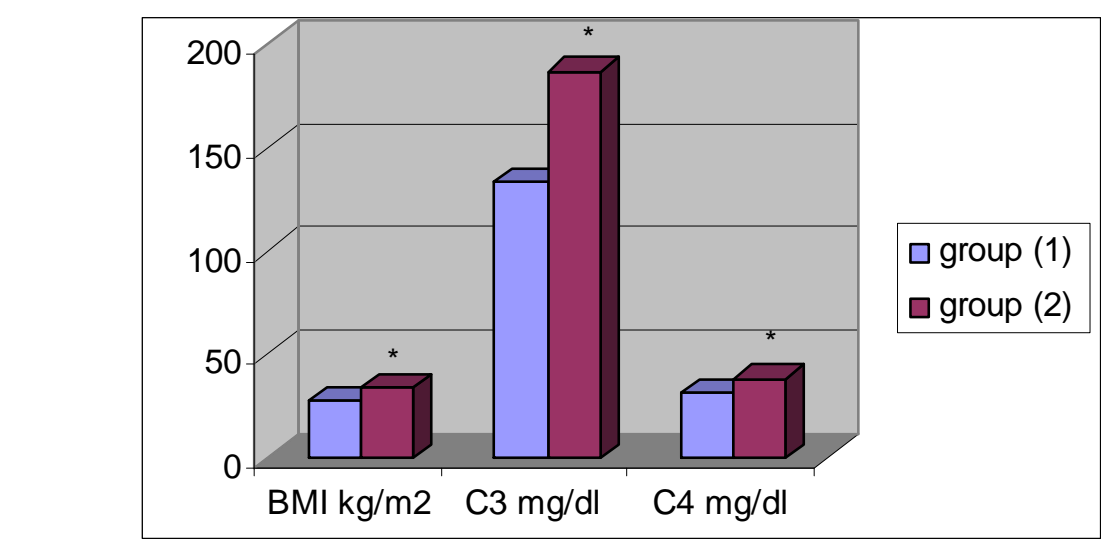

* = significant

Fig. (6) Shows significant differences between groups 1 \& 2 as regards BMI, C3 \& C4 at the end of the study

\section{DISCUSSION}

Complement is a group of serum proteins which work with antibody activity to eliminate pathogens. Complement stimulates inflammation, facilitates antigen phagocytosis, and lyses some cells directly. Because it is such a powerful inflammatory agent, its activity is tightly regulated. Complement $\mathrm{C} 3$ and $\mathrm{C} 4$ are the major plasma proteins of the immune system complement pathways ${ }^{3}$.

Total body fat seems to be associated with a chronic low-grade systemic inflammation in apparently healthy adolescents. Central obesity is 
independently associated with high C3 concentrations. The strong relations of body fat with $\mathrm{C} 3$ and $\mathrm{C} 4$ levels suggested that this increase could be due to an increased production in adipocytes, apart from other complement-producing tissues (i.e, hepatic cells, fibroblast, mononuclear cells, and endothelial cells ${ }^{\mathbf{9}, 12}$.

In the present study, there were significant increases in the levels of both complement proteins C3 \& C4 in obese compared to non-obese female and these increases in complement proteins correlated with the degree of obesity as represented by the body mass index (BMI). This agrees with previous studies, 9 ,13,14. Obese adults have higher $\mathrm{C} 3$ concentrations compared to control subjects ${ }^{13,14}$. Both $\mathrm{C} 3$ and $\mathrm{C} 4$ have shown substantial correlations with obesity, and high gene expression of these complement components has been reported in omental adipose tissue in obese subjects 9 .

Both $\mathrm{C} 3$ and $\mathrm{C} 4$ have been related to complications of obesity in adults ${ }^{15-}$ 17. Activation of the complement system may play a role in the development of macro vascular disease in type II diabetes ${ }^{\mathbf{1 8}}$.

Exercise has been widely believed to be a preventive and therapeutic aid in the treatment of various pathophysiological conditions such as cardiovascular disease and cancer ${ }^{11}$. Recent studies have shown that there are physiological changes in the immune system as a response to exercise. During moderate exercise immune cells circulate through the body more quickly and are better able to kill bacteria and viruses and exercise stimulates macrophage function. After exercise, the immune system activity generally returns to normal within a few hours, but consistent, regular exercise seems to make these changes a bit more longlasting. When moderate exercise is repeated on a near-daily basis there is a cumulative effect that leads to a long-term immune response. However, there is also evidence that too much intense exercise can reduce immunity. Intense exercise seems to cause a temporary decrease in immune system function. Research has found that during intense physical exertion, the body produces certain hormones (Cortisol and adrenaline) that temporarily lower immunity ${ }^{19}$.

In the present study, a group of obese females were subjected to moderate aerobic exercise training three sessions weekly for 4 months and another group of obese females were not subjected to exercise and maintained their ordinary life style. There was a significant weight reduction in the exercise group after the 4 months with decrease of BMI from $32.96 \pm 1.3$ to $27.33 \pm 1.87 \mathrm{~kg} / \mathrm{m}^{2}$ $(\mathrm{P}<0.00)$, while the obese nonexrcised group showed no significant changes in body weight after the 4 months. This agrees with the previous studies which support the role of exercise in weight reduction in obese subjects ${ }^{20-23}$. Some authors explained the effect of exercise on weight reduction by increasing fat oxidation in muscles ${ }^{21}$, others explained that by increasing energy expenditure $^{22,23}$ and some explained that by changes in appetite by the effect of certain hormones ${ }^{\mathbf{2 0}}$.

In the present study, there was a significant reduction in the serum 
levels of complement component $\mathrm{C} 3$ \& C4 in the exercise group with no significant changes in the obese nonexrcised group after the 4 months. This is supported by the previous findings that serum levels of $\mathrm{C} 3$ were higher in obese subjects than in controls and were decreased after weight loss. Also, changes in serum levels of the classical pathway components $\mathrm{C} 1 \mathrm{Q}, \mathrm{C} 2$, and $\mathrm{C} 4$ are correlated with change in body weight in both obese women and those who lost weight due to anorexia ${ }^{14,24}$. Serum C4 levels in both genders correlated with visceral fat area, with high levels of $C 4$ transcripts detected in omental adipose tissue?. Acylation stimulating protein (ASP) which is a precursors of complement component $3 \quad\left(C_{3}\right)$ become higher in obese subjects. Obese humans have 58$400 \%$ increase in (ASP) above normal. Four week fast and exercise resulted in reduction of (ASP) to normal levels in these obese subjects. Weight loss has been shown to decrease ASP levels which decrease atherosclerosis, also plasma C3 decrease with weight loss ${ }^{25}$.

So, in the present study, it was found that a program of moderate intensity exercise for weight reduction, three sessions / week for 4 months lead to significant changes in immune system in the form of the significant reduction of $\mathrm{C}_{3} \& \mathrm{C} 4$ serum levels. This beneficial effect of moderate exercise on the immune system could be related to the significant weight reduction produced by exercise or might be due to direct effect of moderate exercise on the immune system
As there is a dual effect of exercise on the immune system; moderate intensity exercise lowers the incidence of infections while intense exercise increases it. Several studies investigated the underlying mechanisms of such a relationship. Two principal research approaches have emerged in trying to establish a link between exercise and the immune system a metabolic approach that involves glutamine metabolism and another that considers changes in the neuroendocrine milieu as the mechanism for immunomodulation ${ }^{\mathbf{1 9}}$.

Conclusion: obesity causes changes in the immune system in the form of increase in C3 \& C4 levels. Moderate aerobic exercise produced significant weight reduction in obese females and decreased the abnormally elevated complement components (C3 \& C4); so improving the immune system.

\section{REFERENCES}

1. Bray GA and Hassink MD. (2004): Etiology and pathogenesis of obesity. Clinical comers fone 2(3): 1-15.

2. Zhang J, Wright W, Bernlohr DA, et al (2007). Alterations of the classic pathway of complement in adipose tissue of obesity and insulin resistance. Am J Physiol Endocrinol Metab. 292(5): E1433 - E1440

3. Liszewski M, Farries T, Lublin D, et al. (2005): Control of the complement system. Adv. Immunol, 61: 201-283.

4. Pickup JC, Crook MA (1998). Is type II diabetes mellitus a disease of the innate immune 
system? Diabetologia 41,12411248

5. Muscari, A, Massarelli, G, Bastagli, L, et al (2000). Relationship of serum C3 to fasting insulin, risk factors and previous ischaemic events in middle-aged men. Eur Heart J 21,1081-1090

6. Lemieux I, Pascot A, Prud'homme D, et al (2001). Elevated C-reactive protein: another component of the atherothrombotic profile of abdominal obesity Arterioscler Thromb Vasc Biol 21,961-967

7. Weyer C, Tataranni PA, Pratley RE (2000). Insulin action and insulinemia are closely related to the fasting complement $\mathrm{C} 3$, but not acylation stimulating protein concentration Diabetes Care 23,779-785

8. Koistinen HA, Koivisto VA, Ebeling $P$ (2000). Serum complement protein C3 concentration is elevated in insulin resistance in obese men. Eur J Int Med 11,21-26

9. Gabrielsson BG, Johansson JM, Lönn M, et al (2003): High Expression of complement components in omental adipose tissue in obese men. Obesity Research. 11: 699-708.

10. Pool AJ \& Axford JS. The effects of exercise on the hormonal and immune systems in rheumatoid arthritis. Rheumatology 2001; 40: 610-614

11. Luis FB. (2004): Exercise as a time conditioning effectors in chronic Disease. eCAM 1 (1): 6370 .
12. Warnberg J, Nova E, Moreno EA, et al (2006). Inflammatory proteins are related to total and abdominal adiposity in a healthy adolescent population: the AVENA Study. Am. J. Clinical Nutrition; 84(3): 505 - 512.

13. Koistinen HA, Koivisto VA, Ebeling $P$ (2000). Serum complement protein C3 concentration is elevated in insulin resistance in obese men Eur J Int Med 11,21-26

14. Cianflone $K$, Lu H, Smith J, et al (2005). Adiponectin, acylation stimulating protein and complement $\mathrm{C} 3$ are altered in obesity in very young children. Clin Endocrinol (Oxf); 62: 567572

15. Moreno L, Sarría A, Lázaro A, et al (1994). Serum C4 concentration and risk of atherosclerosis. Br Med J; 309: 1087

16. Muscari A, Bastagli L, Poggiopollini G, et al (2002). Different associations of Creactive protein, fibrinogen and C3 with traditional risk factors in middle-aged men. Int $\mathrm{J}$ Cardiol; 83: 63

17. Onat A, Uzunlar B, Hergenc G, et al (2005). Cross-sectional study of complement $\mathrm{C} 3$ as a coronary risk factor among men and women. Clin Sci (Lond); 108: 129

18. Engstrom G, Hedblad B, Eriksson K, et al (2005). Complement C3 Is a Risk Factor for the Development of Diabetes: A Population-Based Cohort Study. Diabetes; 54(2): 570 - 575 
19. Nieman DC, Henson DA, Austin MD, Brown VA (2005). The immune response to a 30 minute walk. Med Sci Sports Exerc; 37:57-62.

20. Davies KM, Heany RP and Recker RP. (2000): Exercise and diet control in treatment of obesity. J clin Endocrinol Metab. 85(12): 4635-4638.

21. Katech FI, Clarkson PM, Krollw ME, et al (2002). Effect of Sit up Exercise Training on Adipose. Cell Size and Adiposity, 55: 242-247.

22. Wilmore JH (2002): Body composition in sport and exercise. Med Sci Sports Exerc;15, 21-31.

23. Ainsworth BE, Haskell WL, Leon AS, et al (2004).
Compendium of physical activities: Classification of energy costs of human physical activities. Med Sci Sports Exerc. 25:71-80.

24. Pomeroy C, Mitchell J, Eckert E, et al (1997). Effect of body weight and caloric restriction on serum complement proteins, including Factor D/adipsin: studies in anorexia nervosa and obesity. Clin Exp Immunol 108,507-515

25. Xia Z, Sinderman AD and Cian flone K. (2002): AcylationStimulating protein (ASP) deficiency induces obesity resistnace and increase energy expenditure in human. 


\section{إستجابة الجهاز المناعي للتمرينات الرياضية في السيدات البدينات}

هدف هذا البحث هو دراسة تأثير التمرينات الرياضية العلاجية على الجهاز الرناعى عند السيدات

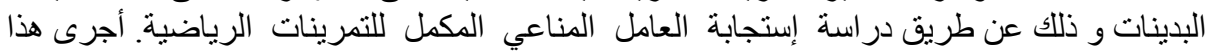

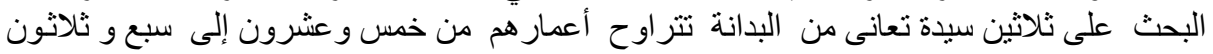
سنة مقسمين إلى مجمو عتنين متساويتين في العين العدد:

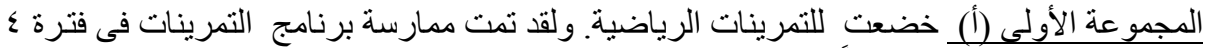

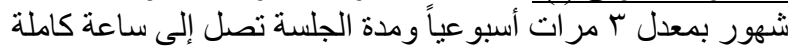

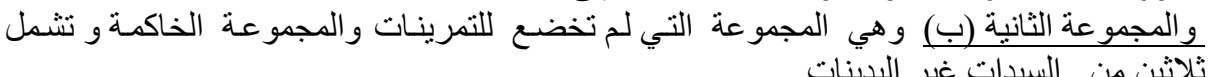
نتائج البحث:

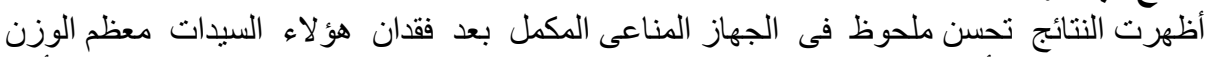

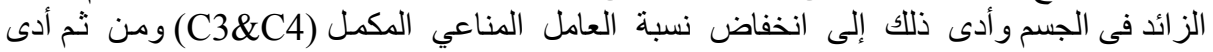

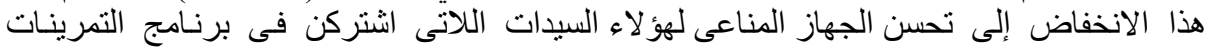

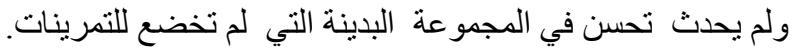

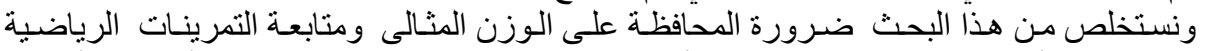

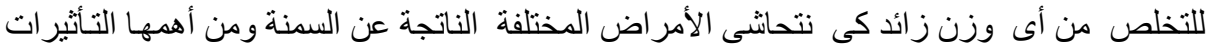
السلبية للسمنة على الجهاز المناعى للجسم وعلى صحة الإنى الإنسان. 